\title{
The Effect of Realistic Mathematic Education on Students' Conceptual Understanding of Linear Progamming
}

\author{
Riyan Hidayat, Zanaton H. Iksan \\ Faculty of Education, Universiti Kebangsaan Malaysia, Bangi, Malaysia \\ Email: riyan160989@gmail.com, zanaton.iksan@ukm.edu.my
}

Received 3 November 2015; accepted 27 December 2015; published 30 December 2015

Copyright (C) 2015 by authors and Scientific Research Publishing Inc.

This work is licensed under the Creative Commons Attribution International License (CC BY). http://creativecommons.org/licenses/by/4.0/

c) (i) Open Access

\section{Abstract}

A number of national and international scale surveys showed that the mathematics achievements of Indonesian secondary school students were in the lower level. One of the indicators of this low achievement was the insufficient level of understanding of mathematical concepts of the students. Understanding of mathematical concepts could be integrated through Realistic Mathematics Education (RME). Therefore, the quasi-experimental study was conducted to examine the effectiveness of Realistic Mathematical Education towards the conceptual understanding of linear programming. The study also investigated the relationship between conceptual understanding and mathematics achievement and investigated the misconceptions on linear programming. This study involved 65 students of Madrasah Aliyah Negeri 1 Pekanbaru, Indonesia. Test conceptual understanding programming topics had Cronbach's alpha reliability of 0.80 . The data were collected by using a test question conceptual understanding of linear programming. Quantitative data analysis involved a descriptive and inferential analysis using SPSS 21.0. The descriptive analysis included the percentage, mean and standard deviation while inferential analysis involving independent t-test and Pearson correlation analysis. The results revealed that there were significant differences between the treatment and control groups toward conceptual understanding. There was a significant relationship between conceptual understanding and mathematics achievement of linear programming. Misconception toward linear programming for the treatment group was lower than the control group. The implications of this study were useful for educators to help their students to understand concept of mathematics through open and contextual questions so that the students though through the mathematics, not worked in the mathematics.

\section{Keywords}

Realistic Mathematics Education, Conceptual Understanding, Misconception, Linear Programming 


\section{Introduction}

The learning process has to provide some benefits for students so that they can develop their ability fully (Nesusin, Intrarakhamhaeng, Supadol, Piengkes, \& Poonpipathana, 2014). Students having a better mathematical understanding will be able to compete in the world economy. Mathematics and Science are a vital component to improve critical society (Ndlovu, 2011) and reasoning ability (Phonapichat, Wongwanich, \& Sujiva, 2014). Success and failure as a society critical can be seen from mathematics and science learning applied in the school. In addition, mathematics is a human activity (Fruedenthal, 1991; Gravemeijer, 1994), linguistic, convention, regulation, and language (Ernest, 1991) where it should be understood by someone through social interaction so that it can realize mathematics knowledge. They have had pre-understanding used as an argument in finding the truth of mathematics. Therefore, cooperation and interaction among many individuals in developing mathematical knowledge are needed. They are given enormous opportunities to learn cooperatively to improve mathematics achievement in order that the teacher's role is to provide rich stimulation in various ways because environment plays an important role to realize fun learning atmosphere. Moreover, academic ability teacher is also another huge factor having to be owned by each teacher (Dudley, 2013; Leong, 2013; Simon, 1995).

Indonesian Education Ministry (2014) states that more than 95\% of Indonesian students solve question on the application level only in Trend in International Mathematics and Science Study (TIMSS). In contrast, nearly 50\% of Taiwanese students have been able to achieve at the reasoning and advance level. Algebra content dimension is the lowest dimension achieved by Indonesian students, who could only $22 \%$ answer correctly. Students show several weaknesses in the understanding, application and reasoning level. Then other studies in algebra also reveal that a lot of students find difficulties to understand the basic concepts (Dogan-Dunlap, 2010; Hidayati, 2010), interpretation (Tanjungsari, Soedjoko, \& Mashuri, 2012), algorithm ability such as planning skill (knowledge strategy) (Bayazit, 2013; Tanjungsari et al., 2012) and appreciate the role of principles in mathematics (Hidayati, 2010; Tanjungsari et al., 2012). For instance, students do not understand algebra operations such as calculations involving $(+,-, \times$ and $\div$ ), students have no algorithmic ability such as lack of planning capabilities (knowledge strategy) and lack of solving ability (algorithmic knowledge), students could not see relationships between an algebraic and an existed mathematical knowledge. In general, therefore, students do not understand algebra concept in a variety of topics well.

Especially on linear programming, Miswanto (2011), Wiwin \& Nurwiani (2009), Win Afgani, Darmawijoyo, \& Purwoko (2008) show that conceptual understanding of students are in the lower level. Error to understand mathematical modelling, translating non-formal knowledge to formal knowledge are sort of misconceptions made by students. For example, they could not understand the word of cost as low as possible or profit as big as possible' where they can merely overcome query such as "calculate minimum or maximum value". Those mistakes can be categorized into three kinds of misconceptions made by the student on linear programming, namely language interpretation, procedural and technical errors (I Made Asih, 2011). As a result, they cannot relate non-formal knowledge to formal knowledge because they do not utilize pre-knowledge to get new knowledge. This is supported by (Coştu, Arslan, Çatlıŏlu, \& Birgin, 2009) asserting that a lot of students who are successful in mathematics, but they are fail to solve real problems in reality.

Looking at problems described above, the teacher should conduct a continuously innovative teaching process because it is one of the topics having the largest part of the curriculum. Several previous studies suggest that to use open problem-based and structured problem-based learning (Herman, 2007), problem solving of real world (Bayazit, 2013; Freudenthal, 1991), a constructivist approach, integrated learning and student-centered technology (Fatimah, Norazzila, \& Rohani, 2013) collaborative learning (Adolphus, Alamina, Aderonmu, Education, \& State, 2013) clinical interviews, error analysis, observation or video recording in resolving problem (Joseph, 2011), diagnostic tests , for improvement toward mathematical thinking ability (Herman, 2007) so that not only on the knowledge and application level, but also on the reasoning level. Therefore, Realistic Mathematic Education (RME) is one of the potential methods including open problem-based, problem solving of real world, collaborative learning and error analysis.

The objectives of this study are to determine whether there are differences in the conceptual understanding linear programming between experiment and control group, to determine whether there is a relationship between conceptual understandings and achievements of linear programming, and to determine the misconceptions that exist in linear programming between experiment and control group. 


\section{Literature Review}

\section{Realistic Mathematic Education (RME)}

RME is defined as contextual learning, which means children learn mathematics through participation to solve real problem in meaningful context (Searle \& Barmby, 2012; Sumitro, 2008). According to Daryanto and Tasrial (2012), theory of RME relate to theory of growing current study, such as constructivism and contextual Teaching and Learning. However, both constructivism and contextual represent general learning theory, RME is an approach specifically developed for learning mathematics. Freudhental (1971) in Daryanto and Tasrial (2012) instead that RME combines the view of what the mathematics, how students learn mathematics and how mathematics should be taught. Based on the above background, a study is conducted by using contextual problems as an effort to enhance student conceptual understanding of mathematics.

The template is used to format your paper and style the text. All margins, column widths, line spaces, and text fonts are prescribed; please do not alter them. You may note peculiarities. For example, the head margin in this template measures proportionately more than is customary. This measurement and others are deliberate, using specifications that anticipate your paper as one part of the entire journals, and not as an independent document. Please do not revise any of the current designations.

\section{Research Method}

This study used a quasi-experimental non-equivalent pretest and post-test control group design. This study involved 65 of students in State High Schools (MAN) 1 Pekanbaru, Riau-Indonesia conducted within 5 weeks with eight-time meetings. Table 1 described percentage of respondent background base on student gender and ability. In experiment groups, there were $42.4 \%$ of male student and $57.6 \%$ of female student while there were $21.2 \%$ of low achiever, $63.6 \%$ of medium achiever and $15.2 \%$ of high achiever. In control group, there were $46.9 \%$ of male and $53.1 \%$ of female student meanwhile there were $18.8 \%$ of low achiever, $59.4 \%$ of medium achiever and $21.9 \%$ of high achiever. The discrimination index in test of conceptual understanding on linear programming from $33.33 \%$ to $61.11 \%$ was good level whereas the index difficulty of items on conceptual under-standing's linear programming from $52.78 \%$ to $69.44 \%$ was moderate level. Conceptual understanding's test on linear programming had Cronbach's alpha reliability of 0.80 which showed reliability of conceptual under-standing's linear programming was good (Lim, 2007). All of the groups were given pre conceptual understanding with the same concept before study was conducted. After revealing some materials, those of groups were given post-test conceptual understanding and achievement to find difference among groups. Score used to evaluate conceptual understanding linear programming topic referred to Rahayu (2013). Students obtaining score of 0,1 and 2 were regarded as students having misconceptions on presented lesson whilst students obtaining score of 3 and 4 were regarded as students having good conceptual understanding.

\section{Results Analysis}

\subsection{Conceptual Understanding of Linear Programming}

For seeing the difference between conceptual understanding linear programming and inferential analysis, independent t-test was conducted. The results of analysis were presented in Table 2.

Table 2 reported that there were significant differences of conceptual understanding linear programming between experiment and control group with $\mathrm{t}=3.639$ and sig. $=0.001(p<0.05)$. This showed the hypothesis (Ho1) that there was no significant difference between students conceptual understanding with RME and traditional approach was rejected. It could be concluded that conceptual understanding linear programming by students ex-

Table 1. Percentage of respondent background.

\begin{tabular}{|c|c|c|c|c|c|}
\hline \multirow[t]{2}{*}{ Group } & \multicolumn{2}{|c|}{ Gender } & \multicolumn{3}{|c|}{ Ability } \\
\hline & Male (\%) & Female (\%) & Low (\%) & Medium (\%) & High (\%) \\
\hline Experiment & 42.4 & 57.6 & 21.2 & 63.6 & 15.2 \\
\hline Control & 46.9 & 53.1 & 18.8 & 59.4 & 21.9 \\
\hline
\end{tabular}


periment group and control group was significantly different.

\subsection{Relationship between Conceptual Understanding and Achievement of Linear Programming}

To determine relationship between conceptual understanding and achievements of linear programming, Pearson correlation analysis was conducted. The analysis of correlation was shown by Table 3 .

Table 3 showed that there was significant relationship between conceptual understanding and achievement of linear programming with $r=0.788$ and sig. $=0.000(p<0.01)$. Analysis of data showed that the relationship between conceptual understanding and achievement of linear programming was high. This indicated the null hypothesis (Ho 3) that there was no significant relationship between conceptual understanding and achievement of linear programming was rejected.

\subsection{Student Misconceptions on Conceptual Understanding of Linear Programming}

Table 4 showed percentage and mean conceptual understanding of linear programming between experiment and control groups.

Table 2. Differences between experiment and control group.

\begin{tabular}{ccccccc}
\hline Group & $\mathrm{N}$ & Min & $\begin{array}{c}\text { Standard } \\
\text { Deviation }\end{array}$ & Value of $\mathrm{d}$ & df & Sig \\
\hline Experiment & 33 & 17.97 & 3.235 & 3.639 & 63 & $0.001^{*}$ \\
Control & 32 & 14.85 & 3.682 & & \\
\hline
\end{tabular}

${ }^{*} p<0.05$.

Table 3. Pearson correlation relationship between conceptual understanding and achievement.

\begin{tabular}{cccc}
\hline & & Conceptual Understanding & Achievement \\
\hline & Pearson correlation & 1 & $0.788^{* *}$ \\
Conceptual Understanding & Sig. (2-tailed) & & 0.000 \\
& $\mathrm{~N}$ & 65 & 65 \\
Achievement & Pearson correlation & $0.788^{* *}$ & 1 \\
& Sig. (2-tailed) & 0.000 & 65 \\
\hline
\end{tabular}

${ }^{* *} p<0.01$

Table 4. Percentage and mean conceptual understanding between experimental and control group.

\begin{tabular}{|c|c|c|c|c|c|c|c|c|c|c|c|c|}
\hline \multirow{3}{*}{ Question } & \multicolumn{6}{|c|}{ Experiment Group } & \multicolumn{6}{|c|}{ Control Group } \\
\hline & \multicolumn{6}{|c|}{ Percentage of Scores } & \multicolumn{6}{|c|}{ Percentage of Scores } \\
\hline & $\mathbf{0}$ & 1 & 2 & 3 & 4 & Mean & $\mathbf{0}$ & 1 & 2 & 3 & 4 & Mean \\
\hline 1 & 0 & 0 & 9.1 & 36.4 & 54.5 & 3.45 & 0 & 3 & 18.2 & 45.5 & 33.3 & 3.09 \\
\hline 2 & 0 & 0 & 24.2 & 51.5 & 24.2 & 3.00 & 0 & 15.6 & 31.3 & 34.4 & 18.8 & 2.56 \\
\hline 3 & 0 & 3 & 30.3 & 39.4 & 27.3 & 2.91 & 6.3 & 3.1 & 34.4 & 37.5 & 18.8 & 2.59 \\
\hline 4 & 0 & 9.1 & 30.3 & 36.4 & 24.2 & 2.76 & 6.3 & 18.8 & 50 & 18.8 & 6.3 & 2.00 \\
\hline 5 & 0 & 6.1 & 15.2 & 48.5 & 30.3 & 3.03 & 3.1 & 9.4 & 28.1 & 46.9 & 12.5 & 2.56 \\
\hline 6 & 3 & 9.1 & 21.2 & 36.4 & 30.3 & 2.82 & 12.5 & 15.6 & 40.6 & 21.9 & 9.4 & 2.00 \\
\hline
\end{tabular}


Table 4 showed that scores of experiment group were higher than control group. The first question, total of 3 (9.1\%) of students of the experiment group and 7 (21.2\%) of control group had misconceptions to answer the first question. The second question showed total of 8 (24.2\%) of experiment group and total of 15 (46.9\%) of control group had misconceptions to answer the second question. The third question showed that 11 (33.4\%) of experiment group and 14 (43.8\%) of control group had misconceptions to answer the third question. The fourth question showed that 11 of (33.3\%) of experiment group, 24 of (75.1\%) control group had misconceptions to answer the fourth question. The fifth question showed total of 7 (21.3\%) experiment group and 13 (40.6\%) of control group had misconceptions to answer the fifth question. The sixth question showed that 11 of (33.3\%) experiment group and total of 21 (68.7\%) of control group had misconceptions to answer the sixth question.

\section{Discussion}

\subsection{Conceptual Understanding Differences between Groups}

The analysis showed that the experiment group was higher conceptual understanding than control group. Worksheet based on RME was the main factor enhancing conceptual understanding student. Students always focused on solution contextual problems phase in which they had stronger conceptual understanding. RME also prioritized the questions without single answer giving opportunities to capitalize on preknowledge. Therefore, they could see past and new knowledge as a unity.

The finding supported study of Smart (2009), Nurhayati and Maulana (2009) and Kawuryan, Sutijan and Budiharto (2012) stating that students taught by RME were able to understand concept well. RME used environment as a learning object so that teaching and learning became meaningful because of that material. Environment presented to students was really close for them so that they not only saw the relevance of mathematical concepts with real environment but also made learning process meaningfully. Environments were presented in a question that did not have single answer in order that it simplified students to do various ways to solve problems.

Students who had a good understanding of the concepts connected to the achievement. This study also supported Muzakkir (2010) and Sumitro (2008) showing that use of RME influenced mathematics achievement. Conceptual understanding of linear programming of experiment groups was higher than control groups in which one factor that can be identified was processes of teaching and learning. Horizontal matematization processes in RME provided opportunities for students to reflect pre-experience and pre-knowledge with various ways. Vertical matematization process provided opportunities for students to make their own statement based on development of model that they confirmed before formal knowledge.

It was an important in RME to develop concept through contextual problem and to apply concept in real problem. Throughout worksheet of RME, students were able to solve realistic problems well and give full explanation about them. The study supported study Searle and Barmby (2012) who stated that students taught by RME had a higher ability to solve problem than students taught by traditional approach. They showed more complete and correct answer according to context question and had more different answer than students by traditional approaches. RME prioritized development of concept through a variety of environments and supported pre-knowledge so that students familiarized with different answers. Afri, Mukhni and Sofia (2011) found that students' problem solving skill with applying RME was better than traditional learning. In RME students were always involved with problem solving. Contextual problem solving was used as development of conceptual understanding and application in real condition. Contextual problem solving in RME also provided simple troubleshooting through several models. The presented models were not only focused on contextual problem solving but also helped students to view the relationship between some prior knowledge, environment and experience. Conceptual Understanding would be a strong conceptual understanding when students learnt through "doing mathematics". Students should be active to construct their own knowledge through interaction with other people and environment. RME gave priority to develop conceptual understanding through "doing mathematics". Therefore, RME gave various examples with environment or experience or knowledge.

\subsection{Relationship between Conceptual Understanding and Mathematics Achievement}

Conceptual understanding and mathematic achievement of linear programming showed a significant relationship that was based on Pearson correlation analysis. Relationship conceptual understanding and mathematic 
achievement of linear programming was very high positive correlation. The finding supported Istikomah and Nor Sakinah (2013) showing that there was a significant relationship between conceptual understanding and mathematic achievement. This meant that conceptual understanding was one of indicators influencing good achievement. Accordingly, Marlina and Nurhidayah (2010) also stated that a higher student achievement demonstrated a higher conceptual understanding.

To improve student achievement in mathematics was needed strong conceptual understanding and even though it would be very important role in mathematic achievement. Good conceptual understanding could solve mathematics problem that related to real life and could make decision critically. According to Hajiyati (2008), a person would fail to answer application questions without good conceptual understanding. It could be concluded that conceptual understanding had strong relationship with a student's achievement. This supported Subhan (2007) who stated that a conceptual understanding was ability to get meaning from an abstract idea till could allow one to classify a particular object or event.

\subsection{Student Misconceptions in Conceptual Understanding of Linear Programming}

Some misconceptions occurred in linear programming was that student could not give a complete explanation on definition of linear programming and mention relevant examples weakly, not been able to analyze and categorize equalities and non-inequalities, not created mathematics modelling or made mistake to interpret contextual problem into mathematics representation, not gave concrete explanation and make a procedural mistake, and error calculations. This finding supported study Win Afgani, Darma and Purwoko (2008), Wiwin and Norwiani (2009), Miswanto (2011) and I Made Asih (2011). Experiment group's misconceptions were smaller than control group student. RME revealed a structured and clear some step learnings by allowing student not loss of procedure in understanding. In addition, teaching and learning process always started with contextual problem as development of concept and not application a concept. Contextual problems were used as a basis for establishing a new concept through matematization or modeling. RME also presented various models that could be developed a stronger conceptual understanding. Bull et al. (2010) stated that the best effective to detect student misconception was through modeling. The model required them to translate from informal experience or knowledge to formal concept. Students would solve problems based on their own pre understanding or pre knowledge until could provide sort of answers or interpretations. Thus, teacher could identify concept that had been owned them before they were introduced to formal concept. Otherwise Karagoz and Cakir (2011) confirmed that traditional teaching could not change student's misconception because it did not consider how to solve contextual problem.

This study did not investigate the effect of RME toward achievement and student misconceptions details, ac-cording to gender and the ability. In addition, RME did not extensively discuss a variety of topics at the secondary school level so that research can be conducted in the appropriate topics in secondary school. In applying PMR, drafting of the opened contextual questions took an important role to build a supported environment in order provided opportunities for students to engage in the learning process. RME was a learning process not only working in mathematics, but also taught students to think mathematically. Therefore, researcher proposed to explore various advantages RME on a variety of skills such as creative thinking skills, critical and communication skills and character education.

\section{Conclusion}

The results showed that there were significant differences between experiment and control groups toward conceptual understanding. Besides that, there was a significant relationship between conceptual understanding and mathematic achievement of linear programming while misconceptions on linear programming for experiment group were lower than control group. The implications of this study could help educators address conceptual understanding through contextual questions so could encourage mathematical thinking and not working in mathematics.

\section{References}

Afri, Mukhni, \& Sofia (2011). Penerapan pendekatan matematik realistik ke atas kemahiran pemecahan masalah murid kelas 2 SMP Negeri 3 Painan tahun pelajaran 2012/2013. STKIP PGRI Sumatera Barat.

Bayazit, İ. (2013). An Investigation of Problem Solving Approaches, Strategies, and Models Used by the 7th and 8th Grade 
Students When Solving Real-World Problems. Educational Sciences: Theory \& Practice, 13, 1-25. http://dx.doi.org/10.12738/estp.2013.3.1419

Bull, S., Jackson, T. J., \& Lancaster, M. J. (2010). Students’ Interest in Their Misconceptions in First Year Electrical Circuits and Mathematics Courses. International Journal of Electrical Engineering Education, 47, 307-318. http://dx.doi.org/10.7227/IJEEE.47.3.6

Coştu, S., Arslan, S., Çatlığlu, H., \& Birgin, O. (2009). Perspectives of Elementary School Teachers and Their Students about Relating and Contextualizing in Mathematics. Procedia-Social and Behavioral Sciences, 1, 1692-1696. http://dx.doi.org/10.1016/j.sbspro.2009.01.300

Daryanto, \& Tasrial (2012). Konsep Pembelajaran Kreatif. Yogyakarta: Gava Media.

Dogan-Dunlap, H. (2010). Linear Algebra Students’ Modes of Reasoning: Geometric Representations. Linear Algebra and Its Applications, 432, 2141-2159. http://dx.doi.org/10.1016/j.laa.2009.08.037

Dudley, P. (2013). Teacher Learning in Lesson Study: What Interaction-Level Discourse Analysis Revealed about How Teachers Utilised Imagination, Tacit Knowledge of Teaching and Fresh Evidence of Pupils Learning, to Develop Practice Knowledge and So Enhance Their Pupils’ Lea. Teaching and Teacher Education, 34, 107-121. http://dx.doi.org/10.1016/j.tate.2013.04.006

Ernest, P. (1991). The Philosophy of Mathematics Education. London: The Falmer Press.

Fatimah, R., Norazzila, S., \& Rohani, A. T. (2013). Exploring Student’s In-Depth Learning Difficulties in Mathematics through Teachers' Perspective. Procedia-Social and Behavioral Sciences, 97, 339-345. http://dx.doi.org/10.1016/j.sbspro.2013.10.243

Fruedenthal, H. (1991). Revisiting Mathematics Education. Dordrecht: Kluwer Academic Publishers.

Gravemeijer, K. (1994). Developing Realistic Mathematic Education. Ultrec: Freudenthal Institute.

Hajiyati, S. (2008). Peningkatan pemahaman konsep simteri melalui model pembelajaran kreatif dengan permainan matematik. Skripsi, Sukoharjo: Universitas Muhammadiyah Surakarta.

Herman, T. (2007). Pembelajaran Berbasis Masalah untuk Meningkatkan Kemampuan Berpikir Matematis Tingkat Tinggi Siswa Sekolah Menengah Pertama. Educationist, I, 47-56.

Hidayati, F. (2010). Kajian Kesulitan Belajar Siswa Kelas VII SMP Negeri 16 Yogyakarta Dalam Mempelajari Aljabar. Caturtunggal: Universitas Negeri Yogyakarta.

I Made Asih (2011). Peningkatan kemampuan siswa sman 8 Denpasar dalam menyelesaikan soal cerita pokok bahasan Program Linier mata pelajaran Matematika. Jurnal Udayana Mengabdi, 10, 67-71.

Istikomah, E., \& Nor Sakinah, M. (2013). Kesan integrasi geometer’s sketchpad dalam pengajaran ke atas pemahaman konsep trasformasi. Jurnal Pendidikan Matematik, 1, 1-13.

Joseph, Y. K. K. (2011). An Exploratory Study of Primary Two Pupils’ Approach to Solve Word Problems Mathematics Curriculum in Schools with a Primary Aim to Enable Students to. Journal of Mathematics Education, 4, 19-30.

Karagoz. M., \& Çakir, M. (2011). Problem Solving in Genetics: Conceptual and Procedural Difficulties. Summer, 11, 16681674.

Kawuryan, S., Sutijan, \& Budiharto, T. (2012). Pemahaman konsep bangun ruang melalui pendekatan matematika realistik. Tesis Sarjana, Surakarta: Jabatan Pendidikan Matematik, Unversitas sebelas Maret.

Leong, K. E. (2013). Factors That Influence the Understanding of Good Factors That Influence the Understanding of Good Mathematics Teaching. Eurasia Journal of Mathematics, Science \& Technology Education, 9, 319-328. http://dx.doi.org/10.12973/eurasia.2013.939a

Lim, C. H. (2007). Penyelidikan Pendidikan. Pendekatan Kuantitatif dan Kualitatif. Kuala Lumpur: McGraw-Hill Education.

Marlina, A., \& Nurhidayah, U. (2010). Tahap kefahaman pelajar tingkatan dua bagi topik nombor negatif. Johor: Universiti Teknologi Malaysia.

Miswanto (2011). Penerapan model pembelajaran berbasis proyek pada materi Program Linier siswa kelas X SMK Negeri 1 Singosari. Jurnal Penelitian Dan Pemikiran Pendidikan, 1, 60-68.

Muzakkir (2010). Kesan pendekatan matematik realistik (PMR) ke atas pencapian dan sikap pelajar terhadap pelajaran matematik. Tesis Sarjana, Bangi Selangor: Universiti Kebangsaan Malaysia.

Ndlovu, M. C. (2011). University-School Partnerships for Social Justice in Mathematics and Science Education: The Case of the SMILES Project at IMSTUS. South African Journal of Education, 31, 419-433.

Nesusin, N., Intrarakhamhaeng, P., Supadol, P., Piengkes, N., \& Poonpipathana, S. (2014). Development of Lesson Plans by the Lesson Study Approach for the 6th Grade Students in Social Study Subject Based on Open Approach Innovation. Procedia-Social and Behavioral Sciences, 116, 1411-1415. http://dx.doi.org/10.1016/j.sbspro.2014.01.407

Nurhayati, A. N., \& Maulana (2009). Penerapan pendekatan matematika realistik dalam penanaman konsep perkalian dan 
pembagian bilangan bulat. Makalah dibentangkan pada Konferensi Pendidikan Dasar I Tingkat Internasional pada tanggal 10-11 Oktober 2009 di UPI Kampus Sumedang. Universitas Pendidikan Indonesia.

Phonapichat, P., Wongwanich, S., \& Sujiva, S. (2014). An Analysis of Elementary School Students' Difficulties in Mathematical Problem Solving. Procedia-Social and Behavioral Sciences, 116, 3169-3174. http://dx.doi.org/10.1016/j.sbspro.2014.01.728

Searle, J., \& Barmby, P. (2012). Evaluation Report on the Realistic Mathematics Education Pilot Project at Manchester Metropolitan University. Durham: Durham University.

Simon, M. A. (1995). Reconstructing Mathematics Pedagogy from a Constructivist Perspective. Journal for Research in Mathematics Education, 26, 114-145. http://dx.doi.org/10.2307/749205

Smart, A. M. (2009). Introducing Angles in Grade Four: A Realistic Approach Based on the van Hiele Model. Canadian Journal for New Scholars in Education, 2, 1-20.

Subhan, A. (2007). Meningkatkan pemahaman konsep dan sikap peserta didik melalui pelatihan guru dengan VCD pemodelan dan pendampingan pada pembelajaran matematik bercirikan pendayagunaan alat peraga bahan pengahajarn pokok luas bangun datar kelas V SD Sekaran 2 TA 2006/2007. Skripsi, Malang dan Blitar: Unversiti Negeri Malang.

Sumitro, N. K. (2008). Pembelajaran matematika realistik untuk pokok bahasan kesebangunan di Kelas 3 SMP Negeri 3 Porong. Paradigma, 8, 204-218.

Tanjungsari, R. D., Soedjoko, E., \& Mashuri (2012). Diagnosis kesulitan belajar matematika SMP pada materi persamaan garis lurus. Unnes Journal of Mathematics Education, 1, 53-58.

Win Afgani, M., Darmawijoyo, \& Purwoko, M. S. (2008). Pengembangan media website pembelajaran materi program linear untuk siswa sekolah menengah atas. Jurnal Pendidikan Matematika, 2, 47-61.

Wiwin, S. H., \& Nurwiani (2009). Analisis kesalahan menyelesaikan soal program linear siswa kelas XI SMK Tribuana Jombang Tahun 2008/2009. Tesis Sarjana, Sekolah Tinggi Keguruan dan Ilmu Pendidikan PGRI Jombang. 